
* Revista do D.A.F.A.M. (Ar-
quitetura Mackenzie), n.1,
1957. proto-história dos serviços de proteção ao patrimônio histórico e artístico do Estado de São Paulo, trabalho ainda por fazer, assinalará, certamente, a presença de alguns nomes, cuja atividade relevante nos outros setores da vida pública paulista pode, porventura, obscurecer a notável contribuição que ofereceram no sentido de salvar os "restos" e documentos relativos à nossa formação regional. D. Duarte Leopoldo e Washington Luiz devem encabeçar a lista ilustrada por Mario de Andrade, Yan de A. Prado, Taunay, Ricardo Severo, Paulo Duarte, Aguirra, Teodoro Sampaio, etc.

Teodoro Sampaio lutou pela conservação da Igreja do Colégio cuja demolição, então irremediável, fê-lo prometer um levantamento completo daquele ilustre "resto" que hoje andam querendo falsificar. Aguirra acumulou, durante anos e anos, um documentário insubstituível a respeito do retalhamento imobiliário paulista. Paulo Duarte lutou como um leão contra o "vandalismo e o extermínio" que ameaçava os últimos documentos materiais da cultura paulista. Ricardo Severo, embora meio ingênuo e saudosista, promoveu a colheita, feita em parte pela aquarelista Nerfini, em parte pelo desenhista W. Rodrigues, de vasto documentário do colonial brasileiro. Seus herdeiros devem possuir esse valioso acervo. Taunay acumulou durante uma rica existência, uma cópia de dados sobre a história regional que ninguém poderá daqui por diante estudá-la sem recorrer aos seus numerosos volumes. Yan de Almeida Prado conseguiu esse monumento precioso que é a sua Brasiliana, mais respeitada no exterior do que valorizada em São Paulo. Mário de Andrade, primeiro responsável pelo artigo SPHAN em São Paulo, foi o artífice da forma legal que pode por em termos operantes uma intenção da cultura paulista. A todos esses nomes deve a proteção ao patrimônio paulista um esforço relevante.

D. Duarte Leopoldo e Washington Luiz se deve a iniciativa prática de ações que representaram,

\section{Luís Saia}

naquele período, o que de melhor era possível fazer. D. Duarte Leopoldo, cujo zelo religioso não ficava além da inteligência e cultura, realizou um notável trabalho de salvamento de um acervo de peças de arte religiosa, hoje reputado indispensável para o estudo da história das artes em São Paulo: o Museu da Curia Metropolitana. Este trabalho não foi, entretanto, apenas trabalho de amor e curiosidade; representava um legítimo reflexo da sua notável cultura, demonstrada em estudos de história que publicou.

Washington Luiz, além de promover e possibilitar a publicação de grande parte do documentário referente a história paulista (Documentos Interessantes, Inventários e Testamentos, etc.), foi um precursor dos trabalhos de restauração, depois encetados sistematicamente pela atual Diretoria do Patrimônio Histórico e Artístico Nacional. À sua ação se deve estarem de pé monumentos como o de Embú e de Itanhaém. Se erros houve nos trabalhos então realizados, foram erros de ordem técnica, erros de deficiência do aparelhamento mental. Erros daquela mesma ordem técnica responsável pelo "colonial" da atual Faculdade de Direito e de tantos monstrengos arquitetônicos que pretendiam formalisticamente se vincular ao passado paulista.

Além dessa contribuição substancial, o que restou do arquivo fotográfico de W. Luiz - arquivo generosamente posto à disposição da SPHAN - serviu ainda como documento de relevante importância para as obras de restauração realizadas nos monumentos de Embú e casa do sítio do Padre Ignácio. A recomposição do alpendre da casa do sítio do Padre Ignácio foi fundamentada num pedaço de coluna encontrada e na fotografia desenhada do referido arquivo. O mesmo aconteceu com a fachada da Igreja e Residência dos Jesuítas, em Embú. 